\title{
Generation of reactive oxygen species in 1-methyl-4-phenylpyridinium (MPP+) treated dopaminergic neurons occurs as an $\mathrm{NADPH}$ oxidase-dependent two-wave cascade
}

W Michael Zawada ${ }^{1 *}$, Gregg P Banninger ${ }^{1}$, Jennifer Thornton', Beth Marriott', David Cantu', Angela L Rachubinski ${ }^{1}$, Mita Das ${ }^{2}$, W Sue T Griffin ${ }^{1}$ and Susan M Jones ${ }^{3}$

\begin{abstract}
Background: Reactive oxygen species (ROS), superoxide and hydrogen peroxide $\left(\mathrm{H}_{2} \mathrm{O}_{2}\right)$, are necessary for appropriate responses to immune challenges. In the brain, excess superoxide production predicts neuronal cell loss, suggesting that Parkinson's disease (PD) with its wholesale death of dopaminergic neurons in substantia nigra pars compacta (nigra) may be a case in point. Although microglial NADPH oxidase-produced superoxide contributes to dopaminergic neuron death in an MPTP mouse model of PD, this is secondary to an initial die off of such neurons, suggesting that the initial MPTP-induced death of neurons may be via activation of NADPH oxidase in neurons themselves, thus providing an early therapeutic target.
\end{abstract}

Methods: NADPH oxidase subunits were visualized in adult mouse nigra neurons and in N27 rat dopaminergic cells by immunofluorescence. NADPH oxidase subunits in N27 cell cultures were detected by immunoblots and RTPCR. Superoxide was measured by flow cytometric detection of $\mathrm{H}_{2} \mathrm{O}_{2}$-induced carboxy- $\mathrm{H}_{2}$-DCFDA fluorescence. Cells were treated with MPP+ (MPTP metabolite) following siRNA silencing of the Nox2-stabilizing subunit p22 ${ }^{\text {phox }}$ or simultaneously with NADPH oxidase pharmacological inhibitors or with losartan to antagonize angiotensin II type 1 receptor-induced NADPH oxidase activation.

Results: Nigral dopaminergic neurons in situ expressed three subunits necessary for NADPH oxidase activation, and these as well as several other NADPH oxidase subunits and their encoding mRNAs were detected in unstimulated N27 cells. Overnight MPP+ treatment of N27 cells induced Nox2 protein and superoxide generation, which was counteracted by NADPH oxidase inhibitors, by siRNA silencing of $\mathrm{p} 22^{\text {phox }}$, or losartan. A two-wave ROS cascade was identified: 1) as a first wave, mitochondrial $\mathrm{H}_{2} \mathrm{O}_{2}$ production was first noted at three hours of MPP+ treatment; and 2) as a second wave, $\mathrm{H}_{2} \mathrm{O}_{2}$ levels were further increased by 24 hours. This second wave was eliminated by pharmacological inhibitors and a blocker of protein synthesis.

Conclusions: A two-wave cascade of ROS production is active in nigral dopaminergic neurons in response to neurotoxicity-induced superoxide. Our findings allow us to conclude that superoxide generated by NADPH oxidase present in nigral neurons contributes to the loss of such neurons in PD. Losartan suppression of nigral-cell superoxide production suggests that angiotensin receptor blockers have potential as PD preventatives.

\footnotetext{
* Correspondence: wzawada@uams.edu

'Donald W. Reynolds Department of Geriatrics, University of Arkansas for

Medical Sciences, Little Rock, AR 72205, USA

Full list of author information is available at the end of the article
} 


\section{Background}

Reactive oxygen species (ROS) contribute to cellular signaling, affecting most aspects of cellular function including gene expression, proliferation, differentiation, and migration $[1,2]$. Under normal physiological conditions, such effects may be beneficial, but an excess of ROS can negatively affect cell function and survival by damaging cellular macromolecules: lipids, nucleic acids, and proteins [3-5]. For example in response to bacterial infection in the brain, a bactericidal oxidative burst is generated by activated microglia [6] and the superoxide produced in this burst results in the oxidative stress, which unabated results in progressive neuronal distresses such as those in PD [7-9]. The oxidative burst induced in activated phagocytes such as neutrophils [10] and microglia [11] comes from superoxide-generating NADPH oxidase.

The NADPH oxidase enzyme consists of several subunits, two of which are permanently membrane bound: the catalytic Nox2 (gp91 ${ }^{\text {phox }}$ ) subunit and the Nox2-stabilizing $\mathrm{p} 22^{\text {phox }}$ subunit. Nox2 has six membrane-spanning domains, two hemes, and a NADPH binding site [12]. Nox 2 interaction with $\mathrm{p} 22^{\text {phox }}$ forms a cytochrome b558 complex, which is necessary for NADPH oxidase activity for production of superoxide through recruitment of a small GTPase Rac2, and of $\mathrm{p} 47^{\text {phox }}$ and p $67^{\text {phox }}$ to the plasma membrane [13]. Formation of the NADPH oxidase complex may involve alternative isoforms of the component subunits [14]. The current database of the human genome contains seven members of the NADPH oxidase family. The members include Nox1-5, together with two dual oxidases (Duox1 and 2) that contain both NADPH oxidase and peroxidase-like domains $[14,15]$; the tissue distribution of these seven family members varies significantly [14]. The gene encoding Nox5 is not present in rodents [16]. Although several pharmacological inhibitors of NADPH oxidase exist $[17,18]$, their specificity, efficacy, and safety differ widely. An alternative and potentially sounder approach to suppression of NADPH oxidase-generated superoxide utilizes angiotensin II type 1 (AT1) receptor blockers, exemplified by the original compound in this class, losartan $[19,20]$. This is possible because generation of superoxide from NADPH oxidase is promoted by angiotensin II binding to the AT1 receptor, leading to induction of protein kinase C-induced Nox2 signaling [19]. Antagonists of the AT1 receptor such as candesartan and losartan suppress angiotensin II-induced increases in superoxide production and Nox2 expression [21].

Postmortem analysis of the midbrain of PD patients has provided evidence of microglial activation in this pathogenic process [22-26]. This activation of microglia, the macrophage-like, resident immune cells of the brain, and ROS production has been associated with the neurodegeneration characteristic of PD [27]. In response to brain injury and immunological challenges, microglia become readily activated and produce a wide array of cytokines and cytotoxic factors, including ROS as well as TNF- $\alpha$, eicosanoids, IL-1 $\beta$, and nitric oxide [28-30]. In one model of dopaminergic degeneration, activation of microglia by the inflammatory factor lipopolysaccharide is rapid and is followed by a delayed, progressive, and selective destruction of nigral dopamine neurons both in vitro and in vivo [31]. Microglial activation significantly enhances MPP+ (1-methyl-4-phenylpyridinium, a metabolite of MPTP, 1-methyl-4-phenyl-1,2,3,6tetrahydropyridine) damage to dopaminergic neurons in a primary neuron-glia cell culture model of dopaminergic cell death [7]. However, this occurs not by direct activation of microglia by MPP+, but rather as a result of microglial stimulation by factors released from an initial die off of dopaminergic neurons. As a result of this sequential neuronal-glial interaction, the primary damage to even a few dopaminergic neurons leads to extensive microglia-enhanced neurodegeneration [7]. Importantly, these findings suggest that ROS responses in dopaminergic neurons, themselves, are a necessary initial step in a cascade that leads to the flagrant neuronal cell loss in response to MPP+ treatment. A link between microglia and NADPH oxidase as mediators of neurotoxicity in experimental models of PD is further supported by findings of a reduction in the loss of dopamine neurons upon exposure to MPP+ in mesencephalic neuron/glia cultures derived from Nox2-deficient mice. In addition, these mice are partly resistant to MPTP treatment $[7,8]$. The binding of MPP + to the mitochondrial electron transport chain complex I results in decreased production of ATP, elevation in superoxide generation, and subsequently cell death.

Babier et al., suggests that NADPH oxidase-induced ROS initially developed as a universal signaling mechanism in all cell types and evolved in macrophages as a means of cellular defense [32,33]. In the CNS, cerebral cortical neurons [34] as well as hippocampal pyramidal neurons [35], cerebellar Purkinje cells [36,37], central autonomic neurons of the intermediate dorsomedial nucleus of the solitary tract [38], and neonatal sympathetic neurons express various subunits of the non-phagocytic NADPH oxidase [39]. While little is known regarding the functions of these subunits in these neuronal cells, two studies point to potential roles in memory formation in the hippocampus [40] and maintenance of growth cone dynamics by F-actin in a giant neuron of a sea snail, Aplysia [41]. The function(s) of the NADPH oxidase Nox2 subunit identified in hippocampal and cortical astrocytes [42] remains undefined. Although microglial NADPH oxidase participates in dopaminergic neurotoxicity [43], whether it also exists in dopamine 
neurons and contributes to the ROS production in the midbrain has not been explored [8].

In this study, we found NADPH oxidase subunits in tyrosine hydroxylase (TH)-immunoreactive neurons of the adult mouse nigra. In addition, expression of NADPH oxidase in a rat nigral dopaminergic cell line, $\mathrm{N} 27$, allowed us to investigate the potential role of $\mathrm{NADPH}$ oxidase in generation of the MPP+ induced ROS. We found that: $i$ ) N27 cells express all the components of NADPH oxidase that are required for its activation; $i$ ) that treatment of these cells with NADPH oxidase inhibitors, or with an angiotensin II type 1 receptor blocker leads to an attenuation of $\mathrm{MPP}+$ induced generation of hydrogen peroxide $\left(\mathrm{H}_{2} \mathrm{O}_{2}\right.$, a product of superoxide dismutation); iii) $\mathrm{MPP}+$ treatment induced a biphasic (two-wave) generation of $\mathrm{H}_{2} \mathrm{O}_{2}$; and iv) NADPH oxidase inhibitors blocked selectively only the second wave of $\mathrm{H}_{2} \mathrm{O}_{2}$ production. These findings support our hypothesis that neuronal NADPH oxidase plays an important role in neuronal stress responses, which contribute to vulnerability of dopaminergic neurons in PD.

\section{Materials and methods}

\section{Animals and cell culture}

Animal protocols and use were in strict accordance with the NIH Guide for the Care and Use of Laboratory Animals and were approved by the Institutional Animal Care and Use Committee at the University of Colorado Denver. We used female C57BL/6J mice from Jackson Laboratories (6 weeks old; 15-18 g) for studies of NADPH oxidase subunit expression in the substantia nigra. Mice were housed individually on a $12 \mathrm{~h}$ light/ dark cycle with food and water available ad libitum.

For all cell culture experiments, we used the N27 dopaminergic cell line derived from rat ventral mesencephalon at gestational day 12. This cell line is often used to model dopaminergic neurons because it expresses the dopaminergic markers $\mathrm{TH}$ and plasma membrane dopamine transporter, and produces dopamine [44]. N27 cells were grown in RPMI medium (CellGro) containing $10 \%$ fetal bovine serum (CellGro), penicillin-streptomycin, L-glutamine, and $1 \mu \mathrm{M}$ angiotensin II (Sigma) in a $37^{\circ} \mathrm{C}$ incubator and $5 \% \mathrm{CO}_{2}$. Cell counts were conducted after trypsinizing N27 cells and counting cells under a hemocytometer. To generate ROS in N27 cell cultures, we treated N27 cells for upto 24 hours with a range of concentrations of MPP+, a metabolite of MPTP. The mechanism by which MPTP exerts toxicity in vivo requires its conversion in astrocytes via monoamine oxidase B to MPP+ (reviewed in [45]). Since the N27 cultures lack astrocytes to perform this conversion, we have treated N27 cells with MPP+ itself. Specific dopaminergic neurotoxicity caused by MPP+ depends on the selective uptake of MPP + via the dopamine transporter into the cytosol where it concentrates inside the mitochondria.

\section{Reagents and antibodies}

$\mathrm{MPP}+$, cyclohexamide (c-hex), apocynin, phenylarsine oxide (PAO) and losartan potassium were obtained from Sigma. Anti-p $47^{\text {phox }}$ and anti-Nox 2 antibodies were from Upstate Biotechnology; anti-p22 $2^{\text {phox }}$ and antip67 ${ }^{\text {phox }}$ antibodies were from Santa Cruz Biotechnology; and anti-TH from Pel-Freez Biologicals. Alkaline phosphatase conjugated anti-rabbit antibody was purchased from Chemicon, anti-goat antibody from Jackson Immunoresearch Laboratories, Lumi-Phos ${ }^{\mathrm{TM}}$ WB from Pierce, propidium iodide from Becton Dickinson, 5-(and-6)-carboxy-2',7'-dichlorodihydrofluorescein diacetate (carboxy$\mathrm{H}_{2}$-DCFDA) substrate dye from Molecular Probes, and Hoechst 33258, and secondary antibodies (Alexa 488 and 568) from Invitrogen.

\section{Immunofluorescent staining}

Six-week-old female C57BL/6J mice were deeply anesthetized and transcardially perfused with saline followed by $4 \%$ paraformaldehyde. The brains were cryoprotected in 30\% sucrose for 2 days before the frozen midbrain region containing nigra was sectioned coronally into $40 \mu \mathrm{m}$-thick sections. Floating sections were rinsed, blocked for 20 minutes in 10\% normal goat serum in Tris-buffered saline (TBS) containing 1\% BSA and $0.1 \%$ Triton $\mathrm{X}-100$, rinsed again, and incubated overnight at room temperature with the following primary antibodies: mouse monoclonal anti-Nox2 (1:750), mouse monoclonal anti-p $47^{\text {phox }}(1: 200)$, mouse monoclonal anti-p67 ${ }^{\text {phox }}(1: 750)$, or rabbit polyclonal anti-TH (1:500). The secondary antibodies were anti-rabbit Alexa 488 (green) and anti-mouse Alexa 568 (red). Fluorescence was imaged in the sections using a Zeiss LSM 510 confocal microscope.

For the immunofluorescent staining of N27 cells grown in 96-well plates, the cultures were rinsed with PBS, fixed in $4 \%$ paraformaldehyde for 1 hour, blocked for 20 minutes with the aforementioned goat serum preparation and incubated with primary antibodies to Nox2, p $22^{\text {phox }}$, and $\mathrm{p} 47^{\text {phox }}$ followed by secondary antibodies as described for the brain sections above. Hoechst 33258 was used to visualize cell nuclei. Images of immunofluorescent detection of antigens and nuclei in N27 cells were acquired using a SPOT camera attached to an inverted Nikon Eclipse TS100 epi-fluorescence microscope.

\section{ROS measurements}

Flow cytometry with carboxy- $\mathrm{H}_{2}$-DCFDA detection identified intracellular $\mathrm{H}_{2} \mathrm{O}_{2}$, which was used as a 
surrogate marker for superoxide generation. Oxidation of this non-fluorescent substrate generates a green fluorescent product. Because the cell membranes are permeable to the esterified form of carboxy- $\mathrm{H}_{2}$-DCFDA, cells uptake it freely. The dye becomes trapped in the cells as a result of deacetylation by intracellular esterases and thus becomes available to oxidation by intracellular $\mathrm{H}_{2} \mathrm{O}_{2}$. Since superoxide is relatively short lived because it is rapidly dismutated to $\mathrm{H}_{2} \mathrm{O}_{2}$, intracellular $\mathrm{H}_{2} \mathrm{O}_{2}$ levels are therefore a more reliable indicator of intracellular ROS burden. For the flow cytometry assay, cells were trypsinized using $0.25 \%$ trypsin-EDTA solution (CellGro) and resuspended in growth medium. Cells $\left(5.0 \times 10^{6}\right)$ were delivered into $5 \mathrm{~mL}$ polystyrene tubes, pelleted, and then incubated for 25 minutes at $37^{\circ} \mathrm{C}$ with carboxy- $\mathrm{H}_{2}$-DCFDA mixed isomers reagent diluted to $2 \mu \mathrm{M}$ in PBS supplemented with $0.5 \%$ FBS (PBSFBS). Cells were then pelleted again and incubated with growth media for 10 minutes at $37^{\circ} \mathrm{C}$ and washed twice with PBS-FBS. In the final step, cells were pelleted, resuspended in propidium iodide solution for $10 \mathrm{~min}$ utes, and carboxy- $\mathrm{H}_{2}$-DCFDA fluorescence emitted by 10,000 live cells was quantified using BD FACScan flow cytometer.

\section{Reverse Transcription PCR and Western blotting}

Total RNA was collected from N27 cells following the Trizol protocol (Invitrogen). Messenger RNA was reverse transcribed using random primers to cDNA with Superscript II (Invitrogen). PCR was performed using NADPH oxidase subunit gene specific primers that yielded PCR products ranging between 400 and $500 \mathrm{bp}$. The following primer sets were designed based on the following accession numbers: rat Nox1 [GenBank: NM_053683] forward: 5'-AGCCATTGGATCACAAC CTC-3'/ reverse: 5'-TGAGGCTCCTGCAACTCCT-3'; rat Nox2 [GenBank:NM_023965] forward: 5'-GTGGAG TGGTGTGTGAATGC-3'/reverse: 5'-AGGATGAGTGACCACCTTGG-3'; rat Nox3 [GenBank:NM_001 004216] forward: 5'-TCTGTAGCATGCCGAGACTG-3'/ reverse: 5'- AATGAACGCCCCTAGGATCT-3'; rat Nox4 [GenBank:NM_053524] forward: 5'-TGTCTGCT TGTTTGGCTGTC-3'/reverse: 5'-AGCAGCAGCAGCATGTAGAA-3'; rat p22 $2^{\text {phox }}$ [GenBank:AJ295951] forward: 5'-TTGTTGCAGGAGTGCTCATC-3'/reverse: 5'CGACCTCATCTGTCACTGGA-3'; rat p40 ${ }^{\text {phox }}$ [GenBank:NM_001127304] forward: 5'-ATGGAAGCTCCAAGAGCAGA-3'/reverse: 5' - AATTGTCCTTCTGG GTGACG-3'; rat p47 ${ }^{\text {phox }}$ [GenBank:NM_053734] forward: 5'-AGCTCCCAGGTGGTATGATG-3'/reverse: 5'TGTCAAGGGGCTCCAAAT-3'; and rat p67 ${ }^{\text {phox }}[$ GenBank:NM_001100984] forward: 5'-TCATGCATGCCAAGAAAGAG-3'/reverse: 5'-CCСТTCTGTCCGTTG AACAT-3'. PCR products were separated by electrophoresis on 1\% agarose gels and visualized with ethidium bromide. Specificity of each primer set was confirmed by amplification of a single band of expected size.

For Western immunoblots, whole cell lysates were made in cell lysis buffer (Promega) supplemented with $1 \%$ SDS, sonicated and separated on precast 4-12\% SDSPAGE gels (Invitrogen). Proteins were then transferred to PVDF membranes and blocked with 5\% milk in TBS with $1 \%$ Tween-20 (TBST). The membranes were then incubated overnight at $4{ }^{\circ} \mathrm{C}$ with the following primary antibodies: anti-p4 $7^{\text {phox }}$, anti-Nox2 (both 1:1000), and anti-p22 $2^{\text {phox }}$ and anti-p67 $7^{\text {phox }}(1: 500$ and $1: 200$, respectively). Membranes were then rinsed, incubated in alkaline phosphatase-conjugated secondary antibodies $(1: 10,000)$, and a chemiluminescent signal was detected using Lumi-Phos ${ }^{\mathrm{TM}}$ WB.

\section{siRNA transfection}

N27 cells were plated at 35,000 cells $/ \mathrm{cm}^{2}$ in antibioticfree RPMI growth medium containing 5\% fetal bovine serum. SiRNA duplexes (siGenome On-Target Smartpool duplex $9 \mathrm{CYBA} / \mathrm{p} 22^{\text {phox }}$ and On-TARGETPlus siControl Non-Target Pool; Dharmacon, Inc) were resuspended in siRNA universal buffer (Dharmacon, Inc) at $20 \mu \mathrm{M}$ and stored in aliquots at $-20^{\circ} \mathrm{C}$. Cells (50$60 \%$ confluent) were transfected twice at 24-hour intervals with $100 \mathrm{nM}$ siRNA and $2 \mu \mathrm{l}$ Lipofectamine 2000 per $\mathrm{ml}$ of Opti-MEM according to the manufacturer's instructions (Invitrogen). After overnight transfection, media were replaced with fresh media for 4-6 hours before second overnight transfection. After the second transfection, cultures were treated with $\mathrm{MPP}+$ for 18 hours and ROS measured as described above. Knockdown of $\mathrm{p} 22^{\text {phox }}$ expression was verified using RT-PCR as described above.

\section{Statistics}

All data are expressed as means +/- SEM of three independent experiments. One-way ANOVA was used for statistical comparisons of multiple groups followed by a Student-Newman-Keuls post-hoc test. Mean values were considered statistically different when $\mathrm{p}<0.05$.

\section{Results}

NADPH oxidase subunits are expressed in both dopaminergic neurons in the mouse substantia nigra pars compacta and in the rat dopaminergic cell line N27

NADPH oxidase is present in microglia [11], astrocytes [46], and in certain types of neurons in hippocampus and cortex $[46,47]$. Here, in adult mice, we show that dopaminergic $\mathrm{TH}$ immunoreactive neurons in substantia nigra coexpress three of the NADPH oxidase subunits, viz., Nox2, the catalytic subunit responsible for 
superoxide generation, as well as the two subunits, $\mathrm{p} 47^{\mathrm{phox}}$ and $\mathrm{p} 67^{\text {phox }}$, necessary for Nox2 activation (Figure 1). The expression was predominantly cytoplasmic, no nuclear localization was observed, and negative control staining by omitting the primary antibody did not produce detectable immunoreactivity (data not shown). While all $\mathrm{TH}$-immunoreactive neurons expressed these subunits, occasionally cells lacking $\mathrm{TH}$ expressed some subunits, suggesting that dopaminergic neurons are not the only cell type in substantia nigra capable of assembling the NADPH oxidase enzyme. Non-TH immunoreactive cell candidates that express NADPH oxidase may include other neuronal cell types, or more likely microglia and astrocytes [48], which when activated are known to express high levels of this enzyme $[11,49]$.

Expression of mRNA for all the subunits of NADPH oxidase, including NADPH oxidase subunits $\mathrm{p} 22^{\text {phox }}$, $\mathrm{p} 47^{\text {phox }}$, and $\mathrm{p} 67^{\mathrm{phox}}$, as well as the cytosolic regulatory

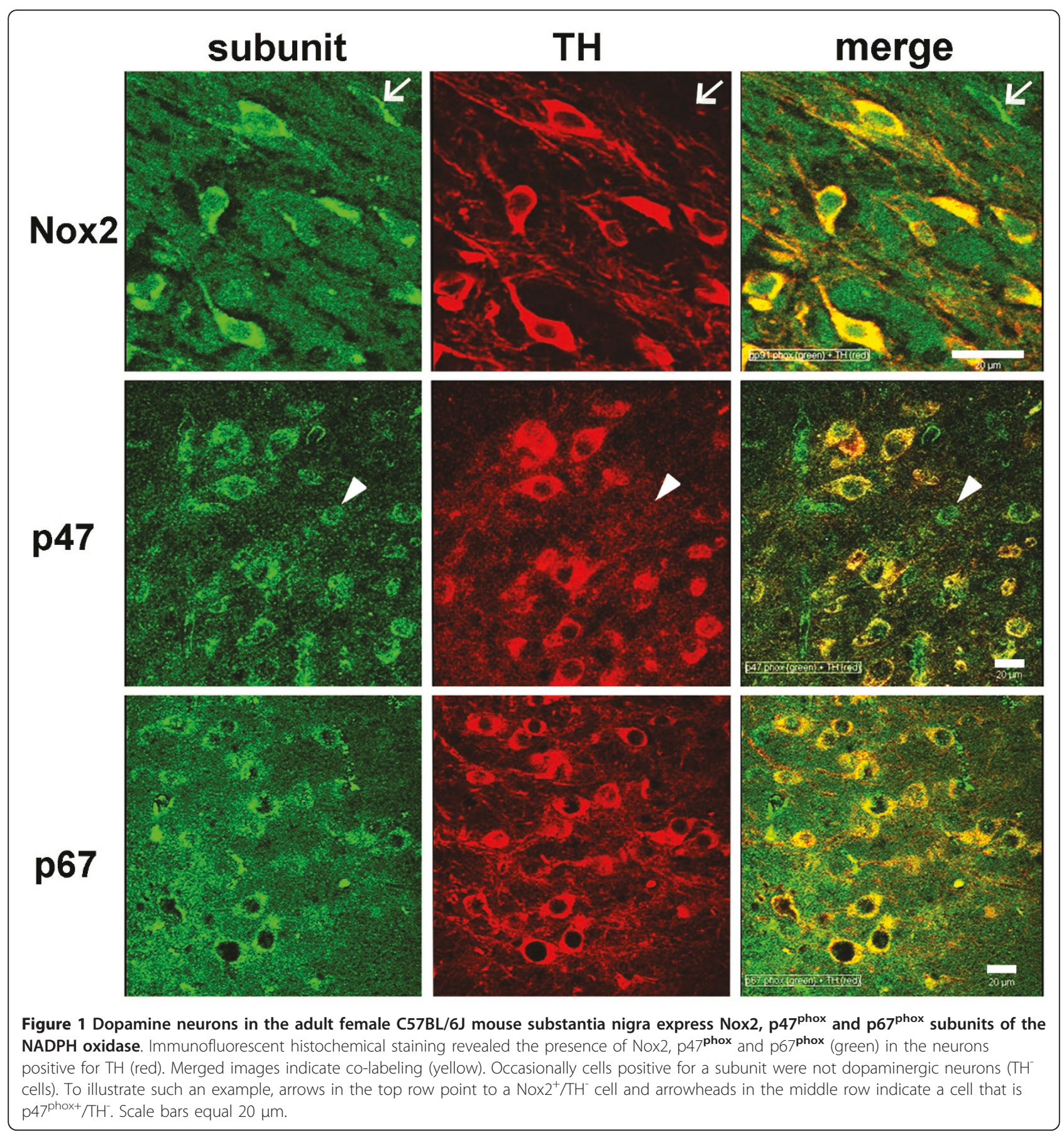


NADPH oxidase subunit $\mathrm{p} 40^{\text {phox }}$ mRNA, which is less involved in superoxide production, and the four Nox homologues is present in the nigral dopaminergic neuronal cell line N27 (Figure 2A). Western blotting and immunofluorescence histochemistry of Nox2, p22 phox, and $\mathrm{p} 47^{\text {phox }}$ confirmed the translation of these mRNAs in N27 (Figure 2B-D). The presence of p67 ${ }^{\text {phox }}$ was confirmed by fluorescence immunoreactivity in nigral dopaminergic neurons in Figure 1.

The dopaminergic neurotoxin MPP+ induces an increase in intracellular ROS in the $\mathbf{N} 27$ dopaminergic cell line $\mathrm{MPP}+$ treatment of the dopaminergic N27 cell line served here as a surrogate in vitro model of the in vivo MPTP-treatment model of PD. In accordance with neurons in normal substantia nigra (Figure 1), N27 dopaminergic neurons have all the subunits necessary to produce superoxide via Nox pathways. Treating N27 cells with increasing amounts of $\mathrm{MPP}+$, the active metabolite of MPTP, corresponded to a dose-dependent increase in the production of superoxide, which peaked at a 20-fold increase (Figure 3A). In addition, exposure to $\mathrm{MPP}+$ at a constant level $(300 \mu \mathrm{M})$ led to a timedependent increase in $\mathrm{H}_{2} \mathrm{O}_{2}$ accumulation that was first detected at three hours and plateaued at 21 hours (Figure $3 \mathrm{~B})$.

MPP+ binding to mitochondrial complex I engenders the initial wave of ROS production

The potential of $\mathrm{MPP}^{+}$binding to mitochondrial complex I in generation of ROS was previously shown in competition studies in which $\mathrm{C}^{14}$-labeled rotenone competed with $\mathrm{MPP}+$ for binding to sub-mitochondrial particles [50]. Rotenone-treatment of MPP+ treated N27 cell cultures results in a fifty percent suppression of $\mathrm{H}_{2} \mathrm{O}_{2}$ production (Figure 4). As complex I is necessary for electron transport-dependent ATP production, it may be that MPP+ binding to mitochondrial complex I

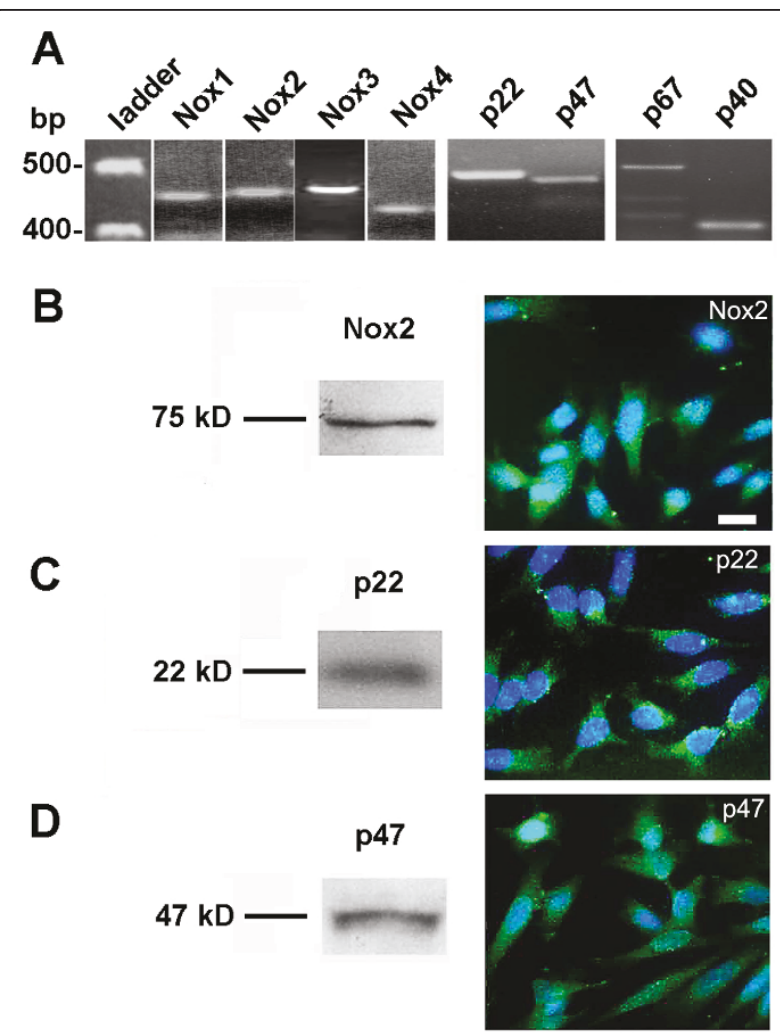

Figure 2 Dopaminergic cells express subunits of the NADPH oxidase complex. (A) mRNA from untreated N27 cells was reverse transcribed and amplified using PCR primers specific to rat NADPH oxidase subunits. Nox 1-4 subunits as well as p22 ${ }^{\text {phox }}, \mathrm{p} 40^{\text {phox }}$, $\mathrm{p} 47^{\text {phox }}$, and $p 67^{\text {phox }}$ were identified by their mRNA expression. Nox2, p22 $2^{\text {phox }}$, and $\mathrm{p} 47^{\text {phox }}$ were also detected by their protein expression (Western immunoblot, B-D) and cellular localization (immunofluorescence, B-D). Scale bar equals $10 \mu \mathrm{m}$; all three micrographs were taken at the same magnification.

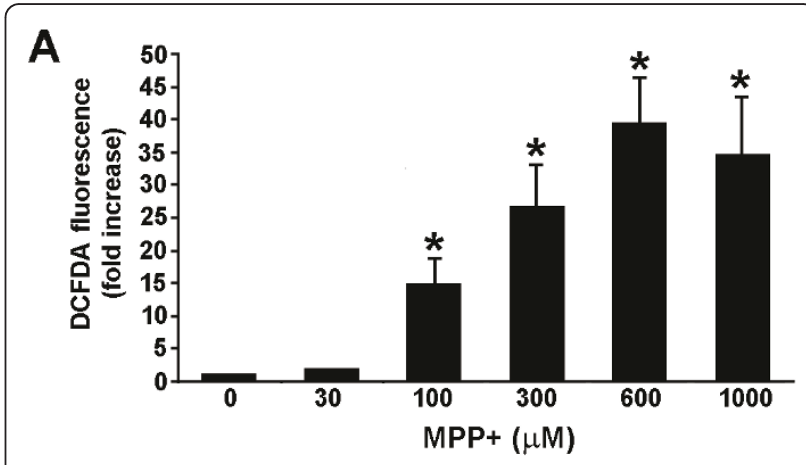

B

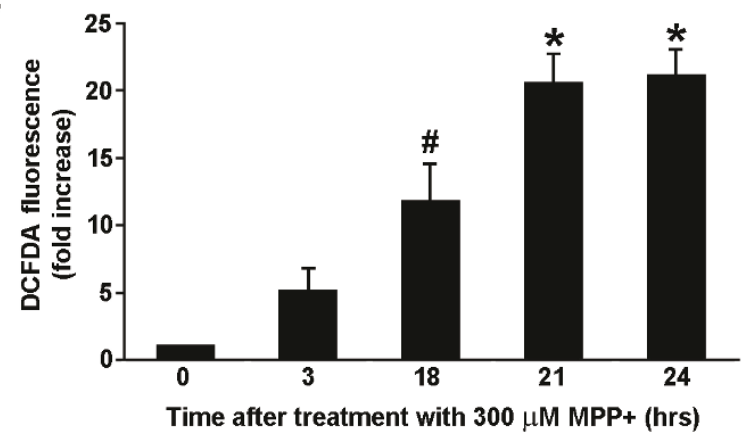

Figure $3 \mathrm{MPP}+$ induces a dose- and time-dependent increase in intracellular ROS in the N27 dopaminergic cells. (A) N27 cells were treated with increasing concentrations of MPP+ (up to 1000 $\mu M)$ for 18 hours and $\mathrm{H}_{2} \mathrm{O}_{2}$ (ROS) levels were measured using carboxy- $\mathrm{H}_{2}$-DCFDA fluorescence and flow cytometry. ROS levels are reported as fold increase above values observed in cells that received no $\mathrm{MPP}+$, control. * $\mathrm{p}<0.01$ compared to $0 \mu \mathrm{M} \mathrm{MPP}+$ control. (B) N27 cells were treated with $300 \mu \mathrm{M}$ MPP+ and ROS levels were detected at different times after treatment. \# represents $p<0.05$ compared to 0 hour and * represents $p<0.01$ compared to 0 hour. Data are from 3 independent experiments with $n=6$ wells per experiment. 


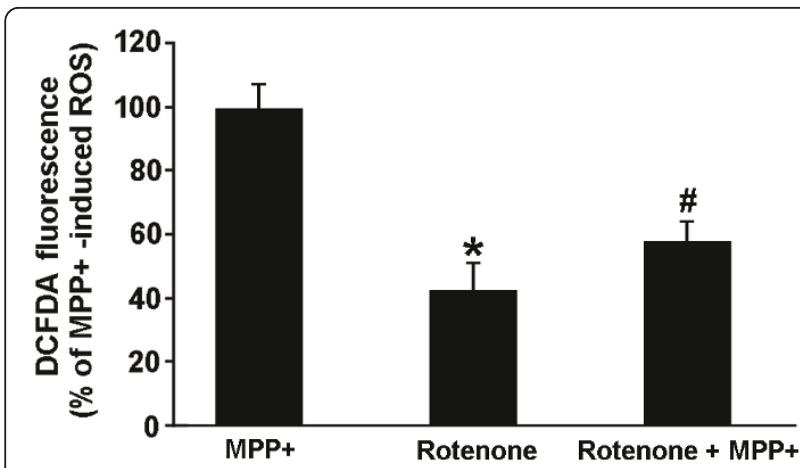

Figure 4 Complex I inhibitor rotenone attenuates MPP+ induced ROS. N27 cells were treated with MPP+ or rotenone alone, or combined for 18 hours. $\mathrm{H}_{2} \mathrm{O}_{2}$ (ROS) levels were measured at that time using carboxy- $\mathrm{H}_{2}$-DCFDA and flow cytometry and are reported as \% of MPP+ induced ROS. * represents $p<0.01$ and \# represents $p<0.05$, both compared to the MPP+ treated cells. Data are from 3 independent experiments with $n=6$ wells per experiment. contributes to cell killing by suppressing ATP generation while increasing superoxide production.

\section{NADPH oxidase contributes to MPP+ induced ROS}

The role of NADPH oxidase in the response of N27 cells to MPP+ treatment was examined by treatment of cells for 18 hours with $300 \mu \mathrm{M} \mathrm{MPP}+$ in the absence or presence of increasing concentrations of NADPH oxidase inhibitors phenylarsine oxide (PAO) or apocynin. Both NADPH oxidase inhibitors led to a reduction in NADPH oxidase activity in a dose dependent manner, with a maximum of $40 \%$ attenuation of the MPP+ induced NADPH oxidase-mediated ROS effect at doses of $10 \mu \mathrm{M}$ apocynin (Figure 5A) and $100 \mathrm{nM}$ PAO (Figure $5 \mathrm{~B}$ ). To further validate the role of the NADPH oxidase in MPP+ driven generation of ROS, we genetically suppressed the expression of the $\mathrm{p} 22^{\text {phox }}$ subunit, which
A

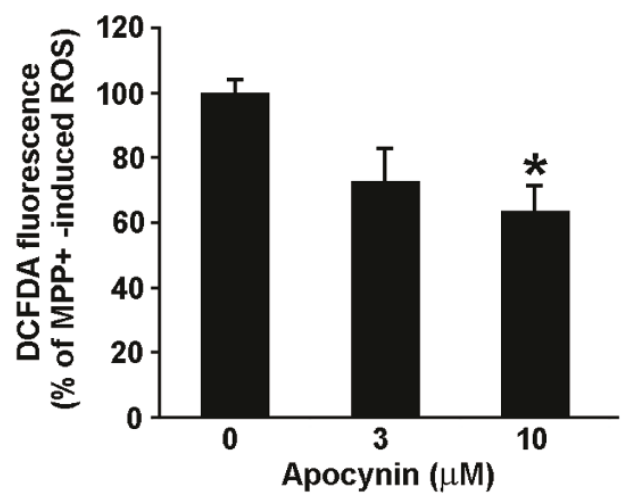

C RT-PCR

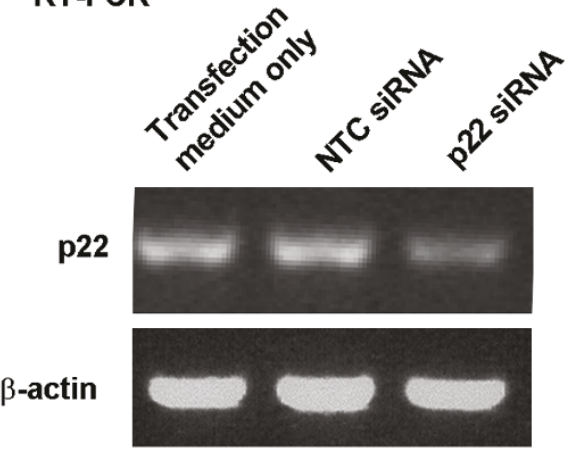

B
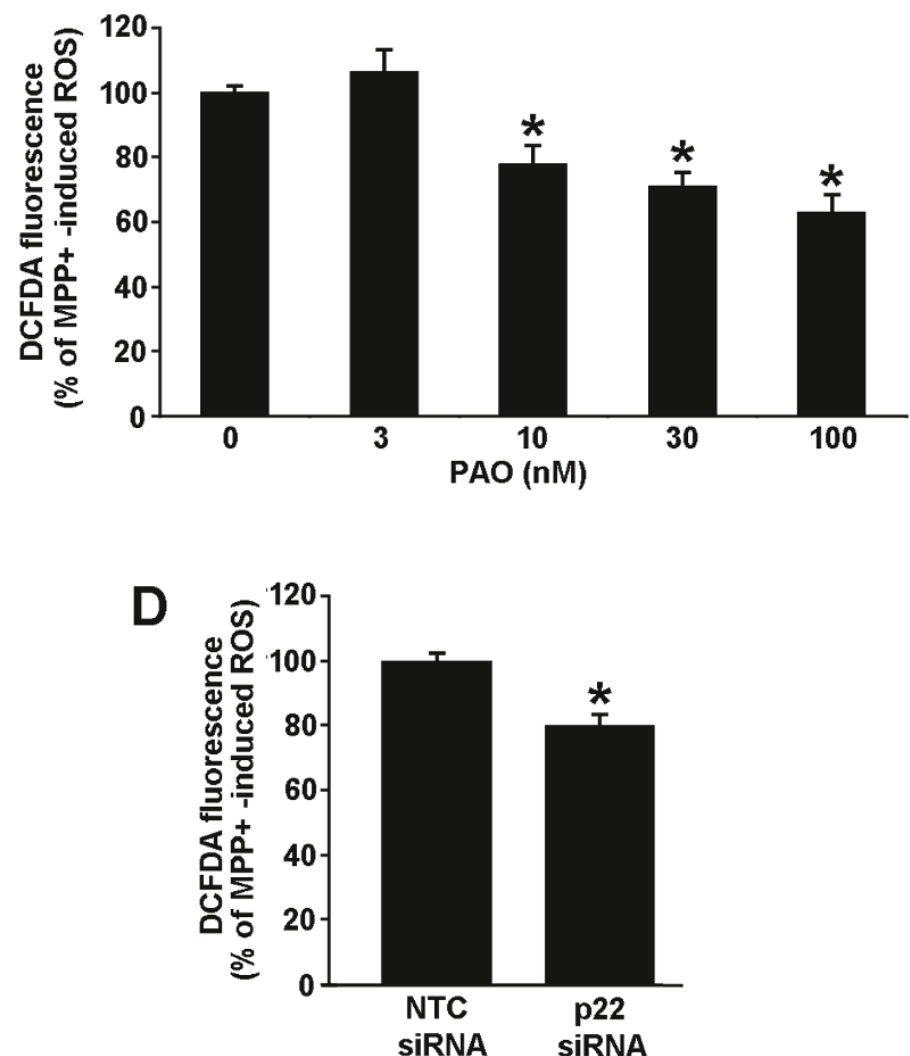

Figure 5 Pharmacological inhibitors of NADPH oxidase and silencing p22 ${ }^{\text {phox }}$ using siRNA attenuate MPP+ induced ROS. N27 cells were treated for 18 hours with $300 \mu \mathrm{M}$ MPP+ and increasing concentrations of either apocynin (A) or phenylarsine oxide (PAO) (B). $\mathrm{H}_{2} \mathrm{O}_{2}$ levels were measured using caboxy- $\mathrm{H}_{2}$-DCFDA and flow cytometry. ROS levels are represented as percent of MPP+ induced ROS. * represents $p<0.05$ compared to cells receiving no inhibitor. (C) N27 cells were transfected with a non-targeting control (NTC) siRNA or a SmartPool siRNA targeting p22 $2^{\text {phox }}$. Total RNA was collected and reverse transcribed to cDNA. Primers complimentary to rat p22 ${ }^{\text {phox }}$ were used to amplify the cDNA. An image of a single representative ethidium bromide-stained agarose gel is shown from one knockdown experiment out of three that produced an average knockdown of 40\%. (D) N27 cells were transfected with NTC or p22 ${ }^{\text {phox }}$ siRNA Smartpool and the intracellular $\mathrm{H}_{2} \mathrm{O}_{2}$ was measured with flow cytometry as described above. * represents $p<0.05$ compared to NTC siRNA-treated cells. Data are from 3 independent experiments with $n=6$ wells per experiment. 
is necessary for the activity of all the Nox isoforms of NADPH oxidase. Such silencing of p22 $22^{\text {hox }}$ mRNA resulted in a 40 percent reduction in $\mathrm{p} 22^{\text {phox }}$ expression compared to a non-targeting control (NTC) siRNA (Figure $5 \mathrm{C}$ ). Although the amount of $\mathrm{p} 22^{\text {phox }}$ silencing in these cells is restricted by the limited transfection efficiency, the examination of ROS levels in p $22^{\text {phox }}$ versus NTC siRNA-transfected cells revealed a significant $20 \%$ attenuation of MPP + induced ROS production (Figure 5D). This gene silencing approach yielded a decrease in ROS production that was similar to that achieved by maximally effective concentrations of NADPH oxidase inhibitors PAO and apocynin.

\section{NADPH oxidase produces a delayed ROS response} following MPP+ treatment suggestive of a second wave response

As MPP + treatment led to an accumulation of ROS in a time-dependent manner (Figure 3B), N27 cell cultures were treated with $\mathrm{MPP}+$ for three, 6 , or 24 hours in the presence or absence of the NADPH oxidase inhibitor PAO. In the presence of PAO, increases in ROS levels were not suppressed by PAO until treatment times were prolonged to 24 hours, and this increase was not fully suppressed by PAO treatment (Figure 6A). This suggests that ROS production in response to $\mathrm{MPP}+$ treatment occurs in two waves; the first detectable as early as 3 hours can be accounted for by $\mathrm{MPP}+$ binding to mitochondrial complex I, a well known source of oxyradicals [51,52], followed, hours later, by the second wave arising from NADPH oxidase activation. The fact that NADPH oxidase inhibitors selectively suppressed ROS production is consistent with the idea that this second wave of ROS is mediated by extramitochondrial NADPH oxidase.

De novo protein synthesis is required for the second wave of ROS: Potential role of Nox2 synthesis in ROS generation

As ROS are potent signaling molecules that regulate gene expression [53], we examined the possibility that ROS generation in MPP + treated N27 cells requires protein synthesis. The presence of the protein synthesis inhibitor cyclohexamide had no effect on the MPP+ induced ROS levels after three-hours of inhibition, but treatment with cyclohexamide for 6 hours attenuated increase in ROS, suggesting that the second wave of ROS requires de novo synthesis of proteins (possibly NADPH oxidase subunits, Figure 6B).

Treating N27 cells for 24 hours with $300 \mu \mathrm{M} \mathrm{MPP}+$ resulted in death of 45 percent of these cells by that point in time (Figure 7A). This corresponded to an increase in Nox 2 protein expression in these cells as determined by immunofluorescence (Figure 7B) and by

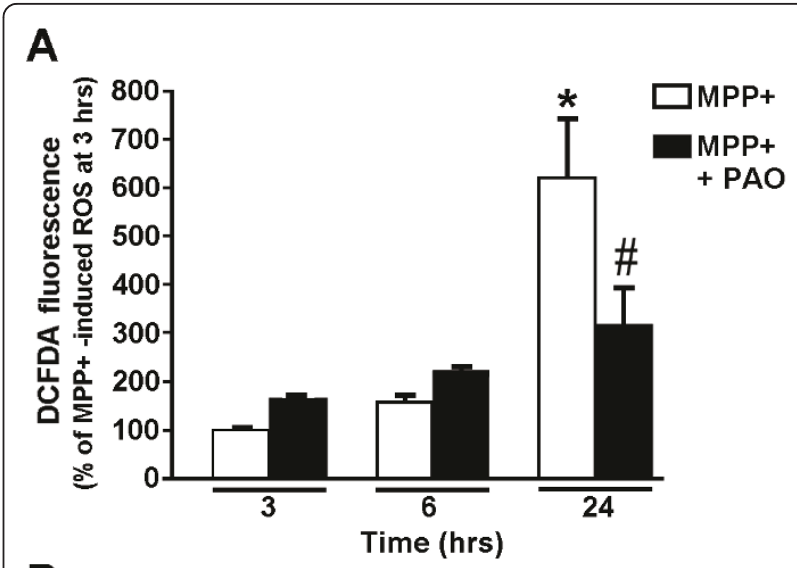

B

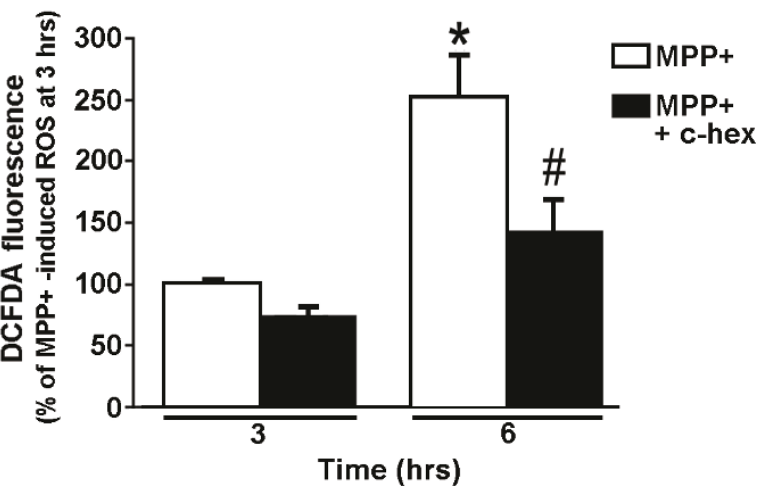

Figure 6 NADPH oxidase inhibitors and an inhibitor of de novo protein synthesis, cyclohexamide, attenuate ROS, but only at later time points after initiation of the MPP+ treatment. (A) N27 cells were treated with $300 \mu \mathrm{M}$ MPP + in the absence or presence of 10 nM PAO. Intracellular ROS levels were measured using carboxy$\mathrm{H}_{2}$-DCFDA and flow cytometry at 3, 6, or 24 hours after initiation of the MPP+ treatment. * represents $p<0.001$ compared to 3 hours MPP+ and \# represents $p<0.001$ compared to 24 hours MPP+. (B) N27 cells were treated with MPP+ for 3 or 6 hours in the absence or presence of the protein synthesis inhibitor cyclohexamide (c-hex). Intracellular $\mathrm{H}_{2} \mathrm{O}_{2}$ levels were measured as described above.

Treatments are plotted as a percent of the 3-hour MPP+ treatment. * represents $p<0.001$ compared to 3 hours MPP+ and \# represents $p<0.05$ compared to 6 hours MPP+. Data are from 3 independent experiments with $n=6$ wells per experiment.

Western immunoblotting (Figure 7C). Nox2 expression, measured by Western blot, was highly sensitive to MPP + as it was increased even at MPP + concentration of 3 $\mu \mathrm{M}$, which was well below the $300 \mu \mathrm{M}$ required for cell killing (Figure 7C).

\section{Angiotensin receptor blocker losartan suppresses MPP+} induced ROS generation

Based on our earlier finding that losartan, an angiotensin-receptor blocker, rescues nigral dopaminergic neurons in the MPTP mouse model of PD [54] via inhibition of the Nox pathway for superoxide generation [11], MPP + treated N27 cultures were co-treated for 18 


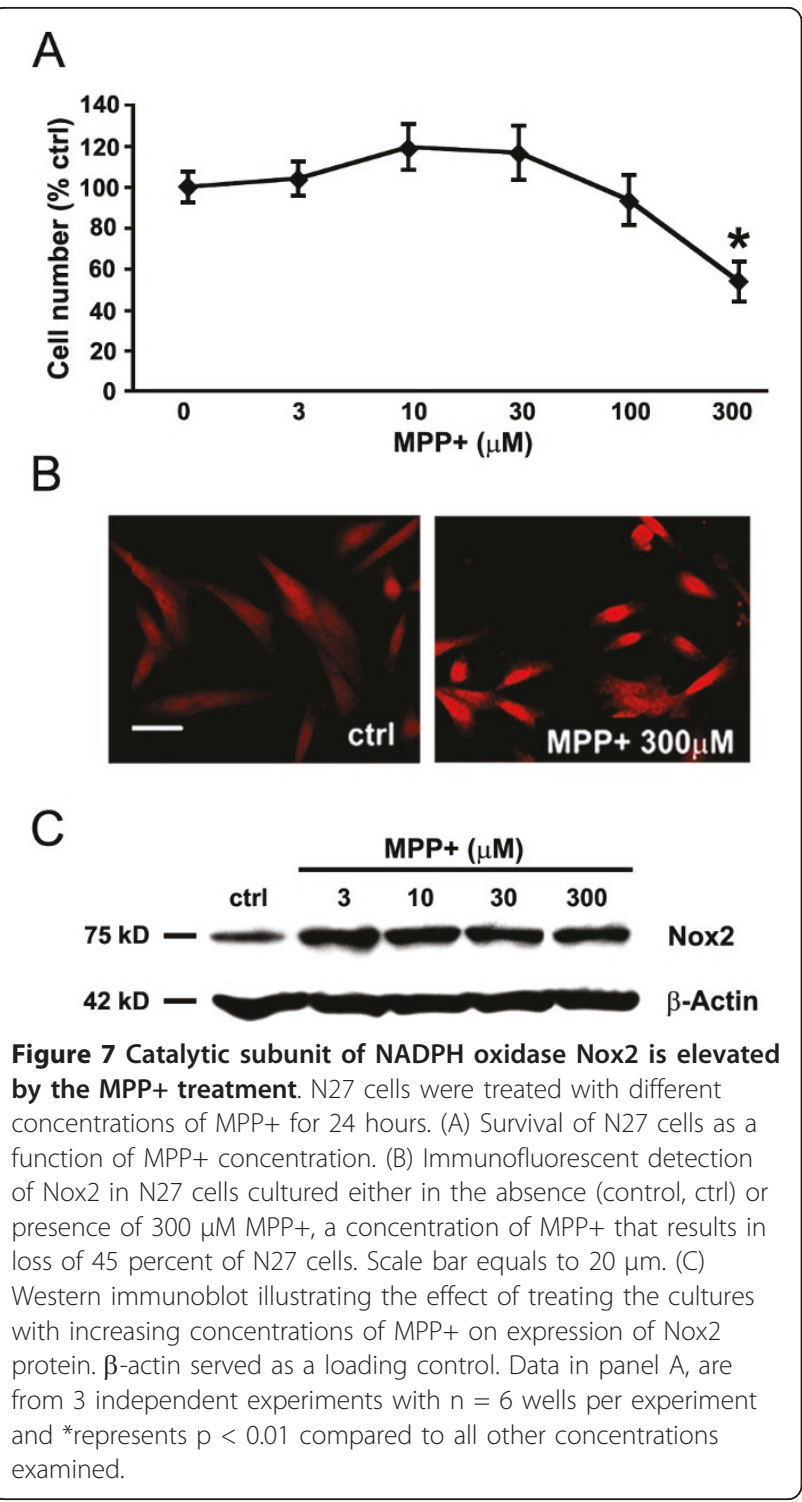

hours with increasing concentrations of losartan. Concentrations of losartan at both 300 and $600 \mu \mathrm{M}$ reduced ROS generation by 30 and 50 percent, respectively (Figure 8).

\section{Discussion}

Previously emphasis was on microglia as agents of dopaminergic neuron cell death in Parkinson's disease. This was based on findings of microglial cell involvement in 6-hydroxydopamine (6-OHDA)-induced superoxide production [55] and diminished mitochondrial ATP production in rat mesencephalic neuron/glia cultures $[55,56]$. However, our discovery of mechanisms by which dopaminergic neurons themselves may contribute to superoxide production adds a further dimension to our understanding of the ways in which such cell death

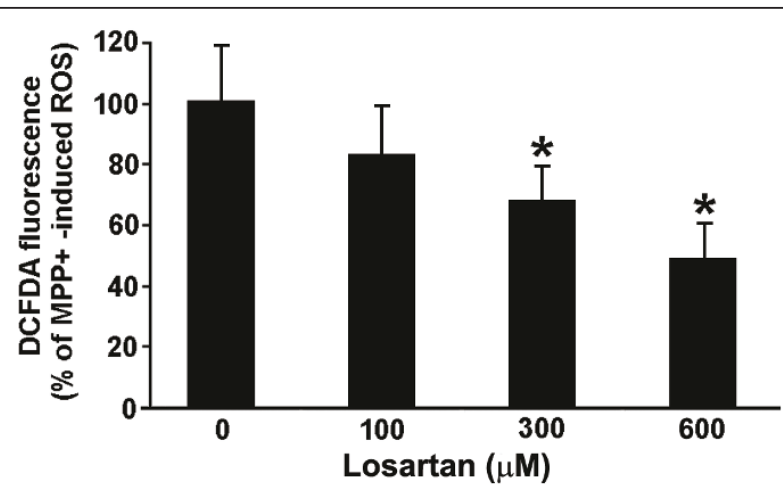

Figure 8 Angiotensin receptor blocker losartan suppresses ROS production. Co-treatment of N27 cultures for 18 hours with $300 \mu \mathrm{M}$ $\mathrm{MPP}+$ and with increasing concentrations of losartan results in dose-dependent reduction in MPP+ induced $\mathrm{H}_{2} \mathrm{O}_{2}$ production. Data are from 3 independent experiments with $n=6$ wells per experiment and * represents $p<0.05$ compared to culture receiving no losartan.

occurs in the face of either environmental neurotoxininduced or idiopathic PD. Furthermore, our demonstration that three of the NADPH oxidase subunits, Nox2, $\mathrm{p} 47^{\text {phox }}$, and $\mathrm{p} 67^{\text {phox }}$ are present in dopaminergic neurons in substantia nigra adds credence to a neuron cell autonomous contribution to the loss of nigral neurons in PD; a contribution that is over and above the known role of Nox $2, \mathrm{p} 47^{\text {phox }}$, and $\mathrm{p} 67^{\text {phox }}$ in microglial production of superoxide-induced cell death.

Here we provide evidence that ROS generation by dopaminergic neurons in response to MPP+ induced neurotoxic stress occurs in two distinct waves. The first wave is the result of $\mathrm{MPP}+$ binding to mitochondrial complex I. The second wave requires protein synthesis for production of extra mitochondrial NADPH oxidase and ROS generation. Identification and characterization of this two-wave cascade of ROS generation provide insight into mechanistic intricacies involved in neurotoxin-stimulated N27 cell death. By analogy to the degeneration of dopaminergic neurons observed in PD models $[43,49,57,58]$ and potentially in idiopathic PD $[59,60]$, our findings provide several novel therapeutic targets. The present report is the first evidence from either dopaminergic or other neuron cell types of a chemical stressor, in this case MPP + , inducing two distinct waves of ROS generation that are characterized by both temporal and cellular compartment separation. The occurrence of an initial wave of ROS production, shown by rotenone competition with MPP+ for mitochondrial complex I ROS generation, which is followed hours later by a second wave of NADPH oxidase-generated ROS suggests that the total burden of a cell's ROS generation may be greater than the sum of wave one and wave two. 
During the completion of the present study, there was a report of such a two wave response in serum starved human embryonic kidney cells [293 HEK(T)] [61]. Serum withdrawal in these cells led to initial elevation of ROS in the mitochondria, followed by generation of Nox-mediated ROS 4-8 hours later, an event dependent on Lyn tyrosine kinase. Silencing Nox1 attenuated this second wave of ROS production in $293 \mathrm{HEK}(\mathrm{T})$ cells, an effect comparable to that observed here with silencing p22 ${ }^{\text {phox }}$ in N27 cells. The notion that NADPH oxidase Nox2-related generation of ROS in neurons is largely extramitochondrial does not preclude generation of ROS from a second intramitochondrial source, as has been reported for Nox4 in mitochondria of cardiac myocytes [62] and of kidney cortical cells [63].

Demonstration of synthesis of Nox $2, \mathrm{p} 47^{\text {phox }}$ and p67 ${ }^{\text {phox }}$, NADPH oxidase subunits that are necessary for mitochondrial complex I-Nox responses to cellular stress in dopaminergic neurons in intact adult substantia nigra, together with evidence of a stress-elicited complex I-Nox response in a MPP + treated dopaminergic cell line (N27) lends credence to the idea that these events are important in PD neuropathogenesis. For example, during hypoxia and reoxygenation of hippocampal and cortical neurons, NADPH oxidase plays a significant role in ROS accumulation at late stages of the stress response [64]. In breast and ovarian tumors, crosstalk between mitochondria and NADPH oxidase requires mitochondrial production of ROS and Nox1 [65], and loss of Nox1 signaling contributes to breast and ovarian tumorigenesis [65]. Because in the current study, the NADPH oxidase inhibitors fail to reduce ROS at early time points following $\mathrm{MPP}+$, and only do so at later times, the reduction in ROS most likely occurred via inhibition of a cellular signaling pathway, and not because of any unforeseen ROS scavenging properties of the inhibitors themselves.

Preliminarily we showed that systemic treatment of mice with losartan, an angiotensin II receptor type 1 antagonist commonly prescribed anti-hypertensive, suppresses MPTP-induced dopaminergic neuron loss and dysfunction in vivo and in vitro [54]. However, the specific mechanisms whereby losartan's salutary effect is brought about was unknown until our current finding that treatment of dopaminergic cells with losartan attenuates MPP+ induced ROS with kinetics suggestive of a temporally-regulated, two-wave response. In addition, a characteristic distinguishing between the waves was shown by the observation that protein synthesis is required for superoxide production in the context of the second wave, but not the first. Thus, we can now say that MPP+ treatment of dopaminergic neurons elicits protein synthesis as a requirement for generation of NADPH oxidase subunit(s), including the catalytic subunit Nox2. Experiments using another neurotoxin, 6OHDA, support such occurrence of de novo synthesis of NADPH oxidase subunits as a part of ROS generation in rat striatal and ventral midbrain tissues [55].

Although it is clear that superoxide is a potent signaling molecule that activates a multitude of signaling pathways [53], the mechanism by which oxidative stress and mitochondrial dysfunction leads to changes in gene expression is unknown. We show here for the first time that the stress-induced initial wave of ROS production comes from mitochondrial respiration, leads to the activation of signaling pathways involved in a second wave of ROS production that depends on protein generation required for assembly and phosphorylation of NADPH oxidase subunits. Therefore, it seems logical that the generation and phosphorylation of a cytosolic subunit(s) of NADPH oxidase is required for setting in motion events giving rise to the second wave. One such example has been suggested to be important in protein kinase Cmediated phosphorylation of $\mathrm{p} 47^{\text {phox }}$, which is required for $\mathrm{p} 47^{\mathrm{phox}}$ translocation from the cytosol to the plasma membrane for the activation of the Nox2 subunit of the NADPH oxidase [14] and initiation of the second wave.

Although the functional significance of the second wave remains to be characterized in full, the two waves in the neuron resulting from-mitochondrial complex I inhibition and extramitochondrial NADPH oxidase activation - may play a role in preconditioning as an adaptive stress response (a.k.a. hormesis) in which brief exposure to a sub-lethal stressor fortifies cellular defenses in an effort to protect cells from a subsequent exposure to severe stress. Such hormetic effects could be explained, for example, by activation of AT1 receptor/Nox pathway by angiotensin II, which elevates activity of key antioxidant enzymes such as catalase, superoxide dismutase and glutathione peroxidase in rat hypothalamus [66]. Furthermore, mitochondrially produced ROS and ATP-sensitive potassium channels have been shown to play a role in the preconditioning machinery [67]. Whether neuronal ROS originating from the two waves act to balance such adaptive machinery awaits assessment.

ROS generation is promoted by angiotensin II binding to the AT1 receptor, which induces a protein kinase $\mathrm{C}$ Nox signaling cascade and leads to elaboration of superoxide from NADPH oxidase [19]. Losartan competes for binding to the AT1 receptor for suppression of angiotensin II-induced increases in ROS production (Figure 9). Although the existence of an extramitochondrial second wave is clear from our data, the specific mechanism (s) by which the mitochondria detect oxidative stress in dopaminergic cells and induce the second wave is unknown, one candidate for mitochondrial oxidative stress recognition has been proposed, viz., inactivation 
of mitochondrial aconitase, an iron-sulfur-containing enzyme necessary for ATP production. Increases in the release of ferrous iron from mitochondrial aconitase catalytic center suggest that iron may function as an oxidative stress biosensor [68,69]. However, it is conceivable that the Nox-induced ROS signals not only affect intracellular signaling pathways that precipitate the two-wave cascade of ROS generation and in this way may influence neighboring cells, including neurons, astrocytes, and microglia, all of which, as we show here in dopaminergic neurons, express NADPH oxidase $[8,70]$. In fact, CD200 ligand expressed on the surface of neurons, but

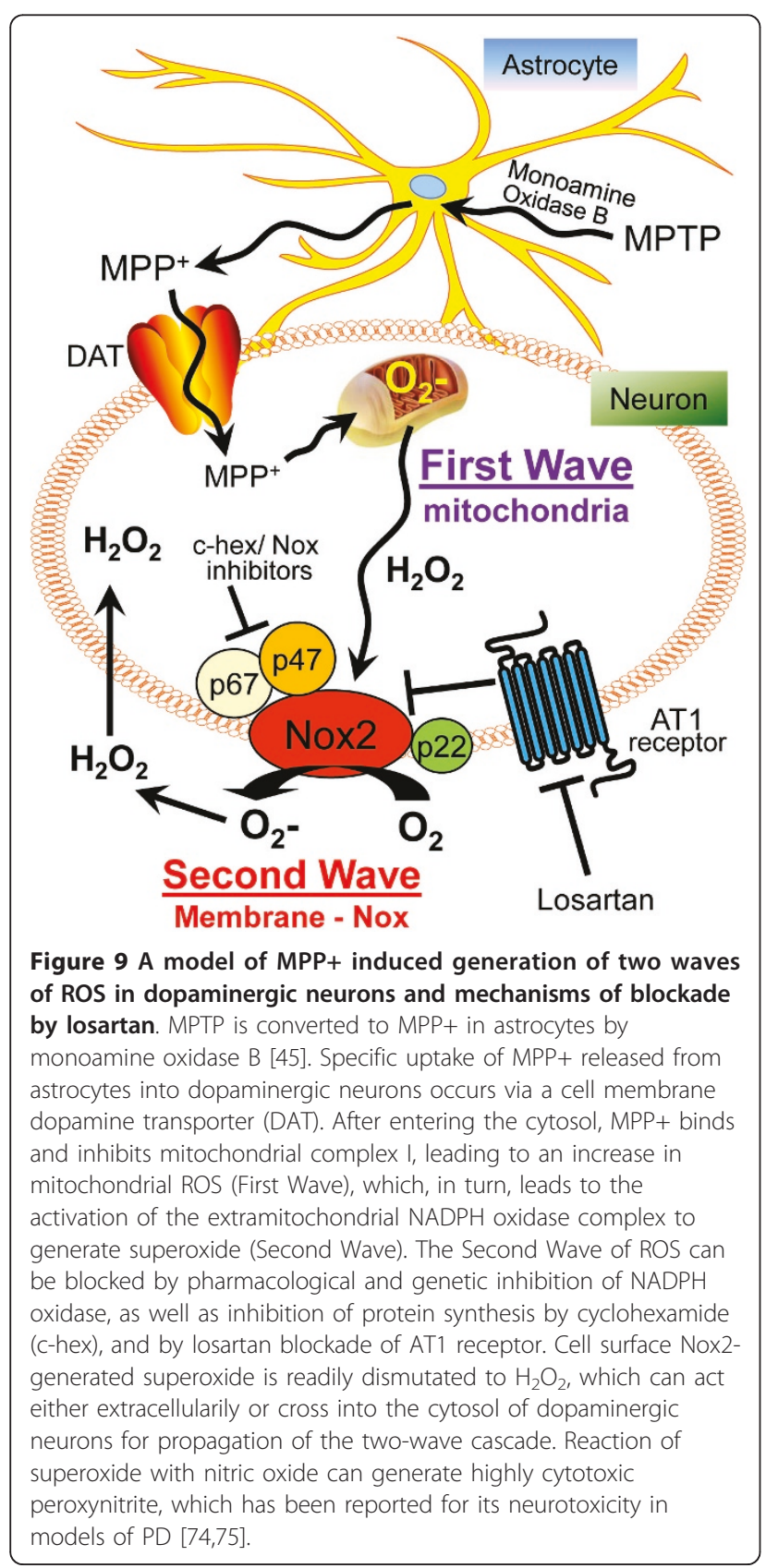

not microglia, interacts with microglial CD200 receptor (CD200R) purportedly maintaining microglia in a resting state [71]. Reduced CD200/CD200R interactions between neurons and microglia may contribute to Parkinson [72] and Alzheimer pathogenesis [73] via activation of microglial NADPH oxidase.

\section{Conclusions}

From our findings that NADPH oxidase subunits are universally expressed in nigral dopaminergic neurons in rats and mice, we conclude that these subunits contribute to ROS generation. The fact that rat N27 cells undergoing neurotoxic stress display a two-wave cascade of oxidative stress, as we show here by treating these cells with $\mathrm{MPP}+$, is consistent with wave one being the result of the binding of MPP+ to mitochondrial complex I. Furthermore, the finding that the second wave can be suppressed by treatment with pharmacological inhibitors of NADPH oxidase implies that the second wave is the result of the activation of extra-mitochondrial NADPH oxidase. The existence of the two waves allows for segregation of ROS production into distinct sub-cellular compartments (Figure 9), suggesting that temporal and translational controls are critical for the trans-compartmental ROS signaling in neurons. Understanding of this process takes a key step toward development of more efficacious preventive or disease-modifying strategies for PD. In addition, such strategies may be useful in other neurodegenerative conditions that are aided and abetted by excessive ROS.

\section{List of Abbreviations}

6-OHDA: 6-hydroxydopamine; AT1: angiotensin II type 1 receptor; ATP: adenosine 5'-triphosphate; CD: cell determinant; C-HEX: cyclohexamide; DAT: dopamine transporter; DCFDA: dichloro-fluorescein diacetate; HEK: human embryonic kidney; MPP+: 1-methyl-4-phenylpyridinium; MPTP: 1-methyl-4phenyl-1,2,3,6-tetrahydropyridine; NADPH: nicotinamide adenine dinucleotide phosphate; NTC: non-targeting control; PAO: phenylarsine oxide; PD: Parkinson's disease; PHOX: phagocytic oxidase; ROS: reactive oxygen species; RT-PCR: reverse transcriptase polymerase chain reaction; TH: tyrosine hydroxylase,

\section{Acknowledgements}

This work was supported by the NIH AA016654 and AG12411. The authors thank Andy M. Poczobutt for technical assistance.

\section{Author details}

1Donald W. Reynolds Department of Geriatrics, University of Arkansas for Medical Sciences, Little Rock, AR 72205, USA. ${ }^{2}$ Department of Pharmacology and Toxicology, University of Arkansas for Medical Sciences, Little Rock, AR 72205, USA. ${ }^{3}$ Neurotrauma Research, Swedish Medical Center, Englewood, CO 80113, USA.

\section{Authors' contributions}

WMZ and MD developed the hypothesis, designed the experiments, and together with WSTG contributed to data analysis and writing of the manuscript. GPB performed experiments with inhibitors and flow cytometry and contributed to writing, JT, BM, DC, ALR conducted experiments and SMJ participated in experiments, data analysis and writing. All authors read and approved the final manuscript. 


\section{Competing interests}

The authors declare that they have no competing interests.

Received: 3 August 2011 Accepted: 5 October 2011

Published: 5 October 2011

\section{References}

1. Rigoulet M, Yoboue ED, Devin A: Mitochondrial ROS generation and its regulation: mechanisms involved in $\mathrm{H}(2) \mathrm{O}(2)$ signaling. Antioxid Redox Signal 2011, 14:459-468.

2. Niethammer P, Grabher C, Look AT, Mitchison TJ: A tissue-scale gradient of hydrogen peroxide mediates rapid wound detection in zebrafish. Nature 2009, 459:996-999

3. Dexter DT, Carter CJ, Wells FR, Javoy-Agid F, Agid Y, Lees A, et al: Basal lipid peroxidation in substantia nigra is increased in Parkinson's disease. J Neurochem 1989, 52:381-389.

4. Alam ZI, Daniel SE, Lees AJ, Marsden DC, Jenner P, Halliwell B: A generalised increase in protein carbonyls in the brain in Parkinson's but not incidental Lewy body disease. J Neurochem 1997, 69:1326-1329.

5. Floor E, Wetzel MG: Increased protein oxidation in human substantia nigra pars compacta in comparison with basal ganglia and prefrontal cortex measured with an improved dinitrophenylhydrazine assay. J Neurochem 1998, 70:268-275.

6. Rock RB, Gekker G, Hu S, Sheng WS, Cheeran M, Lokensgard JR, et al: Role of microglia in central nervous system infections. Clin Microbiol Rev 2004, 17:942-64, table.

7. Gao HM, Liu B, Zhang W, Hong JS: Critical role of microglial NADPH oxidase-derived free radicals in the in vitro MPTP model of Parkinson's disease. FASEB J 2003, 17:1954-1956.

8. Wu DC, Teismann P, Tieu K, Vila M, Jackson-Lewis V, Ischiropoulos H, et al: NADPH oxidase mediates oxidative stress in the 1-methyl-4-phenyl1,2,3,6-tetrahydropyridine model of Parkinson's disease. Proc Natl Acad Sci USA 2003, 100:6145-6150.

9. Kanthasamy A, Jin H, Mehrotra S, Mishra R, Kanthasamy A, Rana A: Novel cell death signaling pathways in neurotoxicity models of dopaminergic degeneration: relevance to oxidative stress and neuroinflammation in Parkinson's disease. Neurotoxicology 2010, 31:555-561.

10. DeChatelet $L R$, McPhail $L C$, Mullikin D, McCall CE: An isotopic assay for NADPH oxidase activity and some characteristics of the enzyme from human polymorphonuclear leukocytes. J Clin Invest 1975, 55:714-721.

11. Joglar B, Rodriguez-Pallares J, Rodriguez-Perez Al, Rey P, Guerra MJ, Labandeira-Garcia JL: The inflammatory response in the MPTP model of Parkinson's disease is mediated by brain angiotensin: relevance to progression of the disease. J Neurochem 2009, 109:656-669.

12. Brandes RP, Kreuzer J: Vascular NADPH oxidases: molecular mechanisms of activation. Cardiovasc Res 2005, 65:16-27.

13. Sumimoto H, Miyano K, Takeya R: Molecular composition and regulation of the Nox family NAD(P)H oxidases. Biochem Biophys Res Commun 2005, 338:677-686.

14. Katsuyama M: NOX/NADPH oxidase, the superoxide-generating enzyme: its transcriptional regulation and physiological roles. J Pharmacol Sci 2010, 114:134-146.

15. Pachucki J, Wang D, Christophe D, Miot F: Structural and functional characterization of the two human ThOX/Duox genes and their $5^{\prime}$ flanking regions. Mol Cell Endocrinol 2004, 214:53-62.

16. Kawahara T, Quinn MT, Lambeth JD: Molecular evolution of the reactive oxygen-generating NADPH oxidase (Nox/Duox) family of enzymes. BMC Evol Biol 2007, 7:109.

17. Anantharam V, Kaul S, Song C, Kanthasamy A, Kanthasamy AG: Pharmacological inhibition of neuronal NADPH oxidase protects against 1-methyl-4-phenylpyridinium (MPP+)-induced oxidative stress and apoptosis in mesencephalic dopaminergic neuronal cells. Neurotoxicology 2007, 28:988-997.

18. Kim JA, Neupane GP, Lee ES, Jeong BS, Park BC, Thapa P: NADPH oxidase inhibitors: a patent review. Expert Opin Ther Pat 2011, 21:1147-1158.

19. Petry A, Weitnauer M, Gorlach A: Receptor activation of NADPH oxidases. Antioxid Redox Signal 2010, 13:467-487.

20. Naik P, Murumkar P, Giridhar R, Yadav MR: Angiotensin II receptor type 1 (AT1) selective nonpeptidic antagonists-a perspective. Bioorg Med Chem 2010, 18:8418-8456.
21. Rueckschloss U, Quinn MT, Holtz J, Morawietz H: Dose-dependent regulation of $\mathrm{NAD}(\mathrm{P}) \mathrm{H}$ oxidase expression by angiotensin II in human endothelial cells: protective effect of angiotensin II type 1 receptor blockade in patients with coronary artery disease. Arterioscler Thromb Vasc Biol 2002, 22:1845-1851.

22. McGeer PL, Itagaki S, Boyes BE, McGeer EG: Reactive microglia are positive for HLA-DR in the substantia nigra of Parkinson's and Alzheimer's disease brains. Neurology 1988, 38:1285-1291.

23. Banati RB, Daniel SE, Blunt SB: Glial pathology but absence of apoptotic nigral neurons in long-standing Parkinson's disease. Mov Disord 1998, 13:221-227.

24. Orr CF, Rowe DB, Mizuno Y, Mori H, Halliday GM: A possible role for humoral immunity in the pathogenesis of Parkinson's disease. Brain 2005, 128:2665-2674

25. Imamura K, Hishikawa N, Sawada M, Nagatsu T, Yoshida M, Hashizume Y: Distribution of major histocompatibility complex class II-positive microglia and cytokine profile of Parkinson's disease brains. Acta Neuropathol 2003, 106:518-526.

26. Croisier E, Moran LB, Dexter DT, Pearce RK, Graeber MB: Microglial inflammation in the parkinsonian substantia nigra: relationship to alphasynuclein deposition. I Neuroinflammation 2005, 2:14.

27. Hirsch EC: Glial cells and Parkinson's disease. J Neurol 2000, 247(Suppl 2): ||58-1|62.

28. Minghetti L, Levi G: Microglia as effector cells in brain damage and repair: focus on prostanoids and nitric oxide. Prog Neurobiol 1998, 54:99-125

29. Lawson LJ, Perry VH, Dri P, Gordon S: Heterogeneity in the distribution and morphology of microglia in the normal adult mouse brain. Neuroscience 1990, 39:151-170.

30. Jeohn GH, Cooper CL, Jang KJ, Liu B, Lee DS, Kim HC, et al: Go6976 inhibits LPS-induced microglial TNFalpha release by suppressing p38 MAP kinase activation. Neuroscience 2002, 114:689-697.

31. Gao HM, Jiang J, Wilson B, Zhang W, Hong JS, Liu B: Microglial activationmediated delayed and progressive degeneration of rat nigral dopaminergic neurons: relevance to Parkinson's disease. J Neurochem 2002, 81:1285-1297.

32. Babior BM: NADPH oxidase. Curr Opin Immunol 2004, 16:42-47.

33. Babior BM: NADPH oxidase: an update. Blood 1999, 93:1464-1476.

34. Noh KM, Koh JY: Induction and activation by zinc of NADPH oxidase in cultured cortical neurons and astrocytes. J Neurosci 2000, 20:RC111.

35. Tejada-Simon MV, Serrano F, Villasana LE, Kanterewicz BI, Wu GY, Quinn MT, et al: Synaptic localization of a functional NADPH oxidase in the mouse hippocampus. Mol Cell Neurosci 2005, 29:97-106.

36. Serrano F, Kolluri NS, Wientjes FB, Card JP, Klann E: NADPH oxidase immunoreactivity in the mouse brain. Brain Res 2003, 988:193-198.

37. Mizuki K, Kadomatsu K, Hata K, Ito T, Fan QW, Kage Y, et al: Functional modules and expression of mouse p40(phox) and p67(phox), SH3domain-containing proteins involved in the phagocyte NADPH oxidase complex. Eur J Biochem 1998, 251:573-582.

38. Glass MJ, Huang J, Oselkin M, Tarsitano MJ, Wang G, ladecola C, et al: Subcellular localization of nicotinamide adenine dinucleotide phosphate oxidase subunits in neurons and astroglia of the rat medial nucleus tractus solitarius: relationship with tyrosine hydroxylase immunoreactive neurons. Neuroscience 2006, 143:547-564.

39. Hilburger EW, Conte EJ, McGee DW, Tammariello SP: Localization of NADPH oxidase subunits in neonatal sympathetic neurons. Neurosci Lett 2005, 377:16-19.

40. Tejada-Simon MV, Serrano F, Villasana LE, Kanterewicz BI, Wu GY, Quinn MT, et al: Synaptic localization of a functional NADPH oxidase in the mouse hippocampus. Mol Cell Neurosci 2005, 29:97-106.

41. Munnamalai V, Suter DM: Reactive oxygen species regulate F-actin dynamics in neuronal growth cones and neurite outgrowth. J Neurochem 2009, 108:644-661.

42. Abramov AY, Canevari L, Duchen MR: Calcium signals induced by amyloid beta peptide and their consequences in neurons and astrocytes in culture. Biochim Biophys Acta 2004, 1742:81-87.

43. Gao HM, Liu B, Zhang W, Hong JS: Critical role of microglial NADPH oxidase-derived free radicals in the in vitro MPTP model of Parkinson's disease. FASEB J 2003, 17:1954-1956.

44. Clarkson ED, Rosa FG, Edwards-Prasad J, Weiland DA, Witta SE, Freed CR, et al: Improvement of neurological deficits in 6-hydroxydopamine- 
lesioned rats after transplantation with allogeneic simian virus 40 large tumor antigen gene-induced immortalized dopamine cells. Proc Natl Acad Sci USA 1998, 95:1265-1270.

45. Singer TP, Ramsay RR: Mechanism of the neurotoxicity of MPTP. An update. FEBS Lett 1990, 274:1-8.

46. Noh KM, Koh JY: Induction and activation by zinc of NADPH oxidase in cultured cortical neurons and astrocytes. J Neurosci 2000, 20:RC111.

47. Hilburger EW, Conte EJ, McGee DW, Tammariello SP: Localization of NADPH oxidase subunits in neonatal sympathetic neurons. Neurosci Lett 2005, 377:16-19.

48. Abramov AY, Jacobson J, Wientjes F, Hothersall J, Canevari L, Duchen MR: Expression and modulation of an NADPH oxidase in mammalian astrocytes. J Neurosci 2005, 25:9176-9184.

49. Gao HM, Liu B, Hong JS: Critical role for microglial NADPH oxidase in rotenone-induced degeneration of dopaminergic neurons. J Neurosci 2003, 23:6181-6187.

50. Ramsay RR, Krueger MJ, Youngster SK, Gluck MR, Casida JE, Singer TP: Interaction of 1-methyl-4-phenylpyridinium ion (MPP+) and its analogs with the rotenone/piericidin binding site of NADH dehydrogenase. $J$ Neurochem 1991, 56:1184-1190.

51. Hasegawa E, Asagami H, Kang D, Minakami S, Takeshige K: 1-Methyl-4phenylpyridinium $(\mathrm{MPP}+)$ inhibits mitochondrial oxygen consumption mediated by succinate as well as malate in rat pheochromocytoma PC12 cells. Biochem Mol Biol Int 1995, 35:409-413.

52. Hasegawa E, Takeshige K, Oishi T, Murai Y, Minakami S: 1-Methyl-4phenylpyridinium (MPP+) induces $\mathrm{NADH}$-dependent superoxide formation and enhances NADH-dependent lipid peroxidation in bovine heart submitochondrial particles. Biochem Biophys Res Commun 1990, 170:1049-1055.

53. Griendling KK, Sorescu D, Lassegue B, Ushio-Fukai M: Modulation of protein kinase activity and gene expression by reactive oxygen species and their role in vascular physiology and pathophysiology. Arterioscler Thromb Vasc Biol 2000, 20:2175-2183.

54. Grammatopoulos TN, Jones SM, Ahmadi FA, Hoover BR, Snell LD, Skoch J, et al: Angiotensin type 1 receptor antagonist losartan, reduces MPTPinduced degeneration of dopaminergic neurons in substantia nigra. Mol Neurodegener 2007, 2:1.

55. Rodriguez-Pallares J, Parga JA, Munoz A, Rey P, Guerra MJ, LabandeiraGarcia JL: Mechanism of 6-hydroxydopamine neurotoxicity: the role of NADPH oxidase and microglial activation in 6-hydroxydopamineinduced degeneration of dopaminergic neurons. J Neurochem 2007, 103:145-156.

56. Misiak M, Beyer C, Arnold S: Gender-specific role of mitochondria in the vulnerability of 6-hydroxydopamine-treated mesencephalic neurons. Biochim Biophys Acta 2010, 1797:1178-1188.

57. Wu DC, Teismann P, Tieu K, Vila M, Jackson-Lewis V, Ischiropoulos $H$, et al: NADPH oxidase mediates oxidative stress in the 1-methyl-4-phenyl1,2,3,6-tetrahydropyridine model of Parkinson's disease. Proc Natl Acad Sci USA 2003, 100:6145-6150.

58. Cristovao AC, Choi DH, Baltazar G, Beal MF, Kim YS: The role of NADPH oxidase 1-derived reactive oxygen species in paraquat-mediated dopaminergic cell death. Antioxid Redox Signal 2009, 11:2105-2118.

59. Qian L, Flood PM, Hong JS: Neuroinflammation is a key player in Parkinson's disease and a prime target for therapy. J Neural Transm 2010, 117:971-979.

60. Tansey MG, Goldberg MS: Neuroinflammation in Parkinson's disease: its role in neuronal death and implications for therapeutic intervention. Neurobiol Dis 2010, 37:510-518.

61. Lee SB, Bae IH, Bae YS, Um HD: Link between mitochondria and NADPH oxidase 1 isozyme for the sustained production of reactive oxygen species and cell death. J Biol Chem 2006, 281:36228-36235.

62. Ago T, Kuroda J, Pain J, Fu C, Li H, Sadoshima J: Upregulation of Nox4 by hypertrophic stimuli promotes apoptosis and mitochondrial dysfunction in cardiac myocytes. Circ Res 2010, 106:1253-1264.

63. Block K, Gorin Y, Abboud HE: Subcellular localization of Nox4 and regulation in diabetes. Proc Natl Acad Sci USA 2009, 106:14385-14390

64. Abramov AY, Scorziello A, Duchen MR: Three distinct mechanisms generate oxygen free radicals in neurons and contribute to cell death during anoxia and reoxygenation. J Neurosci 2007, 27:1129-1138.
65. Desouki MM, Kulawiec M, Bansal S, Das GM, Singh KK: Cross talk between mitochondria and superoxide generating NADPH oxidase in breast and ovarian tumors. Cancer Biol Ther 2005, 4:1367-1373.

66. Silva J, Pastorello M, Arzola J, Zavala LE, De JS, Varela M, et al: AT receptor and $\mathrm{NAD}(\mathrm{P}) \mathrm{H}$ oxidase mediate angiotensin II-stimulated antioxidant enzymes and mitogen-activated protein kinase activity in the rat hypothalamus. J Renin Angiotensin Aldosterone Syst 2010, 11:234-242.

67. Correia SC, Carvalho C, Cardoso S, Santos RX, Santos MS, Oliveira CR, et al: Mitochondrial preconditioning: a potential neuroprotective strategy. Front Aging Neurosci 2010, 2.

68. Cantu D, Schaack J, Patel M: Oxidative inactivation of mitochondrial aconitase results in iron and $\mathrm{H} 2 \mathrm{O}$-mediated neurotoxicity in rat primary mesencephalic cultures. PLoS One 2009, 4:e7095.

69. Cantu D, Fulton RE, Drechsel DA, Patel M: Mitochondrial aconitase knockdown attenuates paraquat-induced dopaminergic cell death via decreased cellular metabolism and release of iron and $\mathrm{H}(2) \mathrm{O}(2)$. J Neurochem 2011, 118:79-92.

70. Abramov AY, Canevari L, Duchen MR: Beta-amyloid peptides induce mitochondrial dysfunction and oxidative stress in astrocytes and death of neurons through activation of NADPH oxidase. J Neurosci 2004, 24:565-575.

71. Wang XJ, Ye M, Zhang YH, Chen SD: CD200-CD200R regulation of microglia activation in the pathogenesis of Parkinson's disease. $J$ Neuroimmune Pharmacol 2007, 2:259-264.

72. Wang XJ, Zhang S, Yan ZQ, Zhao YX, Zhou HY, Wang Y, et al: Impaired CD200-CD200R-mediated microglia silencing enhances midbrain dopaminergic neurodegeneration: Roles of aging, superoxide, NADPH oxidase, and p38 MAPK. Free Radic Biol Med 2011, 50:1094-1106.

73. Walker DG, Dalsing-Hernandez JE, Campbell NA, Lue LF: Decreased expression of CD200 and CD200 receptor in Alzheimer's disease: a potential mechanism leading to chronic inflammation. Exp Neurol 2009, 215:5-19.

74. Li J, Baud O, Vartanian T, Volpe JJ, Rosenberg PA: Peroxynitrite generated by inducible nitric oxide synthase and NADPH oxidase mediates microglial toxicity to oligodendrocytes. Proc Natl Acad Sci USA 2005, 102:9936-9941.

75. Park SU, Ferrer JV, Javitch JA, Kuhn DM: Peroxynitrite inactivates the human dopamine transporter by modification of cysteine 342: potential mechanism of neurotoxicity in dopamine neurons. J Neurosci 2002, 22:4399-4405.

doi:10.1186/1742-2094-8-129

Cite this article as: Zawada et al: Generation of reactive oxygen species in 1-methyl-4-phenylpyridinium (MPP+) treated dopaminergic neurons occurs as an NADPH oxidase-dependent two-wave cascade. Journal of Neuroinflammation 2011 8:129.

\section{Submit your next manuscript to BioMed Central and take full advantage of:}

- Convenient online submission

- Thorough peer review

- No space constraints or color figure charges

- Immediate publication on acceptance

- Inclusion in PubMed, CAS, Scopus and Google Scholar

- Research which is freely available for redistribution 